\title{
Great Power Blame Game: The Ongoing War of Words Over COVID-19. (中文)
}

Edition 3, 2020

Melissa Conley Tyler, Tiffany Liu

DOI: 10.37839/MAR2652-550X2.17

\section{中文 (Chinese translation)}

Over recent weeks, the US and China have used increasingly strong rhetoric around the COVID-19 pandemic. The relationship between the US and China was already bad before the crisis and distrust and animosity have only grown with the war on words over who is responsible for the global pandemic. This had real-life consequences in late March when a meeting of the G7 failed to agree on a joint statement following US State Department's insistence on referring to the coronavirus as the "Wuhan Virus".

How have the two countries been constructing the other as the enemy and what effect has this had on diplomacy in the region?

\section{US Rhetoric: A Crisis Made in China}

From the US side, there is a concerted attempt to make sure that any lasting blame should fall squarely on Beijing. This focuses both on the origin of the virus and China's response.

On 17 March US President Donald Trump tweeted about COVID-19 as the "Chinese Virus". On 18 March, a CBS News journalist quoted a White House official referring to the virus as "Kung Flu". On 19 March Trump's briefing notes were amended to 
replace the word "corona" with "Chinese".

In the early stages of the outbreak in January, the Chinese state media referred to the "Wuhan Virus" but since then, the use of geographic terms has become highly politicised.

World Health Organization (WHO) officials have warned against the use of such terms due to the potential for racial profiling and named the virus COVID-19 to avoid stigmatising one geographical location or group of people. In response to criticisms of his use of "Chinese virus", Trump tweeted on the importance of protecting the Asian-American community.

The other area of US criticism is the Chinese government's response to COVID-19, particularly Beijing's delayed response and lack of transparency. The rhetoric paints China as secretive and untrustworthy, often focusing on China's history of withholding information, such as in its response to Severe Acute Respiratory Syndrome (SARS) in 2003, and the suppression of early warnings of the outbreak in Wuhan including by Dr Li Wenliang. The revision of COVID-19 numbers in Wuhan prompted further scrutiny of China's official figures which many suspect remain conservative.

US Secretary of State Mike Pompeo has been increasingly critical of China's lack of transparency around early details of the outbreak and "the disinformation campaign that the Chinese Communist Party is engaged in to try and deflect from what has really taken place here." Trump re-tweeted a claim by high-profile commentator Andrew McCarthy that China is lied about COVID-19 numbers. Meanwhile, US intelligence released a report to the White House that China is underreporting both total cases and deaths in the country.

On 3 May, Pompeo tweeted that "China has a history of infecting the world", blaming the pandemic on failures in a Chinese lab. He went further to claim that there was "enormous evidence" to support the theory that COVID-19 originated in the Wuhan Institute of Virology and not a wet market, a claim supported by Trump. 
While Secretary Pompeo has since pulled back somewhat, he tweeted on 8 May accusing Beijing of failing to prevent the "deaths of thousands of people worldwide". China has responded promptly by calling out the US's top politicians for their "preposterous allegations" and attempting to quash American claims by casting further doubt on the origins of the virus. In a lengthy 30 page rebuttal, China claimed that the "origin is still not been identified".

Overall, it seems the US strategy is to paint COVID-19 as a "local problem in Wuhan turned into a global pandemic" - as described by a Republican senator - shifting the blame squarely and solely to Beijing. Until the pandemic is contained globally, there is space for the war of words to escalate further, with a bill sponsored by a US Republican senator proposing that citizens and states be able to sue China for COVID-19 related damages.

\section{Chinese Rhetoric: Deflect Blame, Show Leadership}

China has used two strategies in its recent communications: muddying the waters around where the virus originated and showing what it regards as its success in handling the outbreak.

There have been claims from China that COVID-19 could have originated in the US. On 12 March, foreign ministry spokesman Zhao Lijian tweeted "It might be US army who brought the epidemic to Wuhan", linking this with the Military World Games in October. His claim was backed by fellow foreign ministry spokesman Geng Shuang who said there were "varied opinions" on the origin of the virus. This was disavowed by China's ambassador to the US, Cui Tiankai.

By even temporarily injecting doubt on the origins of the coronavirus through this discussion, Beijing hopes to escape blame. The fact that conspiracy theories regarding the virus origin appear to be gaining traction at home is a relative win. It 
shows a shift in the willingness of China's foreign policy establishment to use "wolf warrior" diplomacy to push back against the US, with Chinese President Xi Jinping reportedly ordering diplomats to show "more fighting spirit". An example is the recent suspension of China's embassy in Sri Lanka from Twitter for its posts.

As the epidemic slows in China, officials are presenting it as a victory for the nation. This narrative of war and battle can be seen in Xi's declaration that 'Wuhan must win, Hubei must win, and the whole of China must win' and his statement to UN Secretary-General Antonio Guterres that China will win its battle against COVID-19.

\section{Domestic public is primary audience}

As the virus runs rampant in the US, Washington is fearful of domestic repercussions. For the US, 2020 is an election year and a time when Trump does not want to be seen as responsible for COVID-19. A reason for Trump's initial insistence on terming it the "Chinese virus" may be his confidence in the effect of travel restrictions on China, one of the few early actions his administration took against the virus, which he believes saved tens of thousands of lives.

For China, domestic survival is its priority: preserving the legitimacy and upholding the authority of the Chinese Communist Party. As Bates Gill from Macquarie University puts it, efforts to cast both the party and country in a favourable light as emerging victorious from the pandemic is meant primarily for its domestic audience.

In this context, WHO Director-General Tedros Adhanom Ghebreyesus's praise for the Chinese government's response to COVID-19 as "setting a new standard for outbreak response" is precious. If the US is seen to handle the crisis badly, this can be presented as showing the superiority of China's political and governance system. Hervé Lemahieu, director of the Lowy Institute's Asian Power and Diplomacy Program, describes the "symmetry between the United States and China using the coronavirus as a political football". 


\section{For global public opinion, who will be blamed is important}

China has grasped the opportunity to position itself not as the source of the virus, but a country that helps others: a responsible and humanitarian global power. Zhang Jun, China's ambassador to the UN, has said "We'll do whatever we can to help other countries in fighting the COIVD-19". By offering aid to partners through its "mask diplomacy", China hopes to position itself as a leader, in what the EU's High Representative Josep Borrell has described as the "politics of generosity". The most striking example is Chinese billionaire Jack Ma donating one million masks and hundreds of thousands of testing kits to the US.

It is not clear yet how effective China's "mask diplomacy" will be. There have been cases in the Netherlands, Spain and Turkey of faulty supplies from China. At the same time, Serbia has warmly welcomed the delivery of Chinese products, calling Xi "a brother and friend". There are questions as to whether China's "mask diplomacy" will divert the world's attention. Either way, COVID-19 is a clear opportunity for China to use its economic clout and dominance in global medical supplies for diplomatic ends.

China has also not missed the opportunity to promote the superiority of its own system. On 28 March, the Chinese ambassador to France tweeted that Asian countries, including China, have been particularly successful in the fight against COVID-19 due to a sense of community and good citizenship lacking in Western democracies. He is just one of a growing number of Chinese ambassadors leveraging Twitter - a Western social media platform - to expand Beijing's influence and shape the global information environment. COVID-19 has given China an opportunity to tout its authoritarian system as more successful than the West.

By contrast, the US has yet to show leadership - domestically or internationally - in the same way it did during the Ebola outbreak in East Africa, for instance. While the 
US dealt with Ebola, SARS and Zika with its unparalleled medical research capacity, the current pandemic is proving to be a 'traumatic, overwhelming public health emergency'. How prepared Washington is to lead a global response will depend largely on the president and, under Trump, the instinct is to go it alone. Michael Fullilove from the Lowy Institute views Washington as failing in this current "stress test," criticising the US for being "somewhat febrile and ineffective" under the Trump administration.

There is speculation that Washington's failure to control the virus will result in China seizing a leadership position. Beijing understands that if it is seen as stepping up to the plate where Washington is unwilling or unable to do so, it has the chance to fundamentally shift global politics. As of 8 May, five out of eight human trials to find a COVID-19 vaccine involve Chinese companies or government research institutes. This is critical as Beijing seeks to move past global criticisms and its early reputational hit to emerge as the winner of the COVID-19 battle.

\section{High stakes}

Australia is just one example of a country caught in the war of words between the US and China, particularly on the issue of the origin and spread of the virus.

Some Australian commentators have noted that the majority of cases in Australia have come from the US, Europe and cruise ships (including Minister for Home Affairs Peter Dutton contracting the virus after a visit to the White House) and have argued that flights from the US should have been shut down earlier, if not for double standards.

But more prominent have been the voices that have focused on China's role in covering-up the initial outbreak, such as Nine News political reporter Chris Ullman's characterisation of the Chinese government as "a paranoid and increasingly aggressive totalitarian regime that reflexively lies, controls all media, persecutes and jails its domestic critics and threatens the few nations that challenge it with 
retribution". The Saturday Telegraph published an expose on the Wuhan laboratory theory, reportedly to the surprise of Australian intelligence officials given the scientific evidence.

Australia has announced that it is seeking to establish an international investigation into the pandemic at the annual meeting of the World Health Assembly, as well as suggesting the introduction of health inspectors with the power to enter countries quickly during a crisis.

In response, China's foreign ministry spokesman has accused Australia of "dancing to the tune of a certain country to hype up the situation," suggesting that Australia is a proxy for the US. As Trump promises a conclusive report on the exact origins of COVID-19, it is likely Australia's push for an independent inquiry will be further framed as Canberra trying to please Washington.

China's ambassador to Australia has warned of serious potential consequences for Australia including potential consumer boycotts that will damage key Australian industries like agriculture, education and tourism.

Interestingly, public opinion polling suggests that the Australian public are disappointed in both China and the United States in their responses to the virus. When asked how well countries have handled the COVID-19 outbreak so far, $44 \%$ rate China as having handled it very badly and a whopping $63 \%$ think the United States has handled it very badly. And they believe this poor response will have longterm consequences: only 6\% believe the United States will be more powerful after the crisis while $53 \%$ believe it will be less powerful. By contrast $37 \%$ believe China will be more powerful and $27 \%$ less powerful.

As the epidemic continues, particularly in the US, so will the scapegoating and the narrative war. There is the potential for US-China tension on COVID-19 to further fuel existing economic and security tensions across the region, such as their trade war. Increased tensions will make it harder for China and the US to communicate and cooperate effectively as is essential on this transnational threat. 


\section{MELBOURNE ASIA REVIEW}

Of great concern is the politicisation of the WHO. On 15 April, the US announced that it would halt funding to the WHO which "willingly took China's assurances to face value... and defended the actions of the Chinese government". US-China frictions over the WHO will only grow with a diplomatic push for Taiwan's return to the World Health Assembly. Beijing is already framing this as Washington "trying desperately to distract from its botched coronavirus response". The US's COVID-19 death toll surged above China's official count on 1 April and it currently has the most confirmed cases worldwide.

Which nation will emerge from COVID-19 least damaged? National University of Singapore's Kishore Mahbubani imagines that the world after the pandemic will see "a hobbled West and a bolder China" but former Australian Prime Minister Kevin Rudd imagines that both the US and China will be weakened and damaged at home and abroad after the crisis.

Will the US end up being seen as the victim of external forces or its own mismanagement? Will China end up being seen as the country that unleashed the virus or the one that showed the world how to overcome it? That's why the stakes in this war of words are so high.

Melissa Conley Tyler is Director of Diplomacy at Asialink at The University of Melbourne. She tweets at @MConleytyler. Tiffany Liu is a Master of International Relations student currently interning with Asialink.

This is an updated version of a piece originally published by Melbourne Asia Review on 6 April, "American Bioweapon or the 'China Virus'? The War of Words over COVID-19". It is being featured by the Observer Research Foundation in its Global Policy Series.

Image credit: publicdomainpictures 